\title{
Pemberdayaan Kelompok Tani Hortikultura di Lahan Pasir melalui Pemanfaatan Kayambang (Salvinia molesta) sebagai Trichokompos
}

\author{
The Empowerment of Horticultural Farming Communities on Sandy Lands to Make Use of \\ Kayambang (Salvinia molesta) to become Trichocompost
}

Rahmawati Budi Mulyani*
Lilies Supriati
Melhanah
Susi Kresnatita
Department of Agrotechnology,
Universitas Palangka Raya, Palangka
Raya, Central Kalimantan, Indonesia
Received: November 2020
Accepted: May 2021
Published: June 2021
rahmawati.mulyani@agr.upr.ac.id
Kayambang
Lahan berpasir
Pemberdayaan
Trichokompos
Keywords:
Salvinia molesta
Sandy land
Empowerment
Trichocompost

\begin{abstract}
Abstrak
Gulma rawa lebak seperti Kayambang (Salvinia molesta) tumbuh melimpah dan berpotensi dimanfaatkan sebagai pupuk kompos yang efektif memperbaiki kesuburan tanah, meningkatkan ketersediaan unsur hara $\mathrm{N}, \mathrm{P}$ dan $\mathrm{K}$ secara cepat dan ramah lingkungan. Efektivitas pupuk kompos perlu ditingkatkan dengan menambahkan mikroba indigenus sebagai dekomposer dan agens hayati mengendalikan penyakit tanaman. Kegiatan yang dilakukan untuk memberdayakan kelompok tani hortikultura pada lahan berpasir di Kelurahan Tanjung Pinang, Palangka Raya adalah melalui sosialisasi, pelatihan pembuatan kompos dengan tiga jenis jamur antagonis Trichoderma sp. (Trichokompos), memfasilitasi pengadaan mesin pencacah gulma, pendampingan petani pada budidaya tanaman hortikultura, dan meningkatan kemandirian petani dalam swadaya pupuk organik. Pemanfaatan Kayambang sebagai Trichokompos dengan penambahan mikroba dekomposer dan agens hayati indigenus merupakan pengetahuan yang baru bagi petani mitra dan aplikasi Trichokompos pada demplot menunjukkan pertumbuhan tanaman terung dan hasil panen sangat baik, artinya Trichokompos dapat memperbaiki kesuburan lahan berpasir. Peserta pelatihan menyatakan penggunaan Trichokompos dapat mengurangi biaya usaha tani karena mampu mensubstitusi pupuk kandang yang selama ini digunakan petani dan mampu memenuhi kebutuhan pupuk organik. Peserta menginginkan program pendampingan lanjutan karena petani belum menguasai teknik isolasi maupun perbanyakan agens hayati dan mikroba dekomposer.
\end{abstract}

\begin{abstract}
Lebak swamp weeds such as Kayambang (Salvinia molesta) grow abundantly. They can be used as compost, which effectively improves soil fertility, increasing nutrients $\mathrm{N}, \mathrm{P}$, and P K quickly and environmentally friendly. The effectiveness of compost fertilizer needs to be increased by adding indigenous microbes as decomposers and biological agents to control plant diseases. The activities carried out to empower horticultural farmer groups on sandy land in Tanjung Pinang Village, Palangka Raya are through socialization, training in composting with three types of antagonist fungus Trichoderma sp. (Trichocompost), facilitate the procurement of weed chopping machines, assist farmers in horticultural crop cultivation, and increase farmers' independence in self-supporting organic fertilizers. The use of Kayambang as Trichocompost with microbial decomposers and indigenous biological agents is new knowledge for partner farmers. The application of Trichocompost on the demonstration plots shows that eggplant plant growth and yields are excellent, meaning that Trichocompost can improve the fertility of sandy soils. Farmers participating in the training stated that the use of Trichocompost could reduce farming costs because it can substitute for manure that has been used by farmers and can meet the self-help needs of organic fertilizers. Participants wanted an advanced mentoring program because the farmers had not yet mastered the isolation or propagation of biological agents and decomposer microbes.
\end{abstract}




\section{PENDAHULUAN}

Kelurahan Tanjung Pinang terletak di Kecamatan Pahadut, Kota Palangka Raya memiliki wilayah terluas yaitu 48,26 km2 atau 40,43\% dari luas kecamatan Pahandut (Badan Pusat Statistik Kota Palangka Raya, 2018). Kelurahan Tanjung Pinang menjadi salah satu wilayah yang direncanakan menjadi kawasan untuk pengembangan pertanian terutama pada lahan-lahan marjinal seperti lahan pasir dan lahan rawa gambut lebak untuk budidaya komoditas hortikultura seperti semangka, melon, labu, dan sayur-sayuran seperti terung, cabai, dan tomat (Pemerintah Kota Palangka Raya, 2019). Luas lahan berpasir kuarsa yang terdapat di kelurahan Tanjung Pinang kurang lebih 33, 6 hektar (Firmansyah et al., 2011). Selain itu, di Kelurahan Tanjung Pinang terdapat ekosistem rawa lebak seluas kurang lebih 40 hektar, umumnya merupakan daerah yang terdapat di kiri dan kanan Sungai Kahayan dan anak sungai, dengan topografi datar, tergenang air pada musim penghujan, dan kering pada musim kemarau (Noor, 2007). Karakteristik lahan yang demikian menyebabkan petani di Kelurahan Tanjung Pinang membudidayakan komoditi hortikultura pada dua jenis lahan tersebut menyesuaikan dengan kondisi musim.

Pada umumnya tanah pasir banyak didominasi mineral primer jenis kwarsa $\left(\mathrm{SiO}_{2}\right)$ yang tahan terhadap pelapukan dan sedikit mineral sekunder. Kondisi ini menjadikan tanah pasir merupakan tanah yang tidak subur, kandungan bahan organik dan kandungan unsur hara rendah, pH 5-6, sehingga miskin unsur hara, struktur lepas, efisiensi penggunaan air rendah dan kurang mendukung pertumbuhan tanaman (Holilullah et al., 2015; Hasibuan, 2015).

Untuk mengatasi kendala tersebut petani mitra umumnya menambahkan amelioran berupa kapur pertanian, pupuk kandang ayam dan pupuk anorganik (urea, TSP, KCl). Di sisi lain, gulma Kayambang (Salvinia molesta) tumbuh sangat melimpah di rawa lebak kelurahan Tanjung Pinang terutama ketika musim penghujan, diperkirakan volumenya mencapai 50 - 100 kg per meter kubik lahan. Kayambang tumbuh secara alami di sungai kecil dan saluran irigasi yang ada di lingkungan sekitar tempat tinggal petani. Kayambang mempunyai potensi sebagai sumber bahan organik pembuatan pupuk kompos yang dapat menambah kesuburan tanah pada lahan pasir, dapat memperkecil pori-pori tanah sehingga dapat menahan air dan unsur hara. Kresnatita (2017) melaporkan bahwa dosis bokashi Kayambang (40 t/ha dan Abu 30-40 t/ha) mampu meningkatkan produktivitas tanah gambut an hasil tanaman seledri. Untuk meningkatkan efektivitas pupuk kompos diperlukan sentuhan teknologi terhadap kompos agar memiliki peran bukan saja sebagai sumber unsur hara melainkan berfungsi sebagai pengendali patogen tanah agar tanaman terhindar dari penyakit adalah menggabungkan pupuk kompos dengan agens hayati Trichoderma sp. dikenal sebagai Trichokompos. Agens hayati indigenus seperti T. longibrachiatum secara in vitro mampu menekan Fusarium oxysporum f.sp. cubense penyebab penyakit layu pada pisang hingga 88,2\% (Mulyani et al., 2018). Trichoderma sp. juga berperan sebagai dekomposer yang dapat mengurai bahan organik seperti karbohidrat, terutama selulosa dengan bantuan enzim selulose, dan sebagai stimulator meningkatkan pertumbuhan tanaman (Soesanto et al., 2013). Pupuk Trichokompos dapat mengendalikan penyakit tular tanah seperti Sclerotium sp., Phytium sp., Fusarium sp. dan Rhizoctonia sp. serta meningkatkan pertumbuhan dan produksi bawang merah di lahan berpasir (Supriati et al., 2019). Pupuk kompos sendiri merupakan sumber nutrisi bagi pertumbuhan Trichoderma sp., penggunaan kompos eceng gondok, kayu apu dan kiambang sebagai media aplikatif dapat meningkatkan kemampuan Trichoderma sp. menekan 
intensitas penyakit hawar pelepah (Rhizoctonia solani) dan memicu pertumbuhan tanaman padi di lahan pasang surut (Masruddin et al., 2019). Aplikasi secara berkala Trichokompos pada lahan pasir akan memberikan manfaat yang lebih baik daripada aplikasi pupuk dan fungisida kimia. Tujuan kegiatan adalah memberdayakan kelompok tani dalam memanfaatkan gulma kayambang menjadi Trichokompos hingga mampu swadaya kompos untuk keperluan kelompok tani, memfasilitasi tersedianya peralatan mesin pencacah kompos, dan pendampingan petani mulai dari aplikasi Trichokompos pada demplot budidaya tanaman terung hingga panen.

\section{METODOLOGI}

Kegiatan ini merupakan Program Dosen Pendamping Pemberdayaan Masyarakat (PDPPM) LPPM UPR yang telah dilaksanakan mulai bulan Agustus hingga November 2020 di Kelurahan Tanjung Pinang, Kota Palangka Raya (Gambar 1).

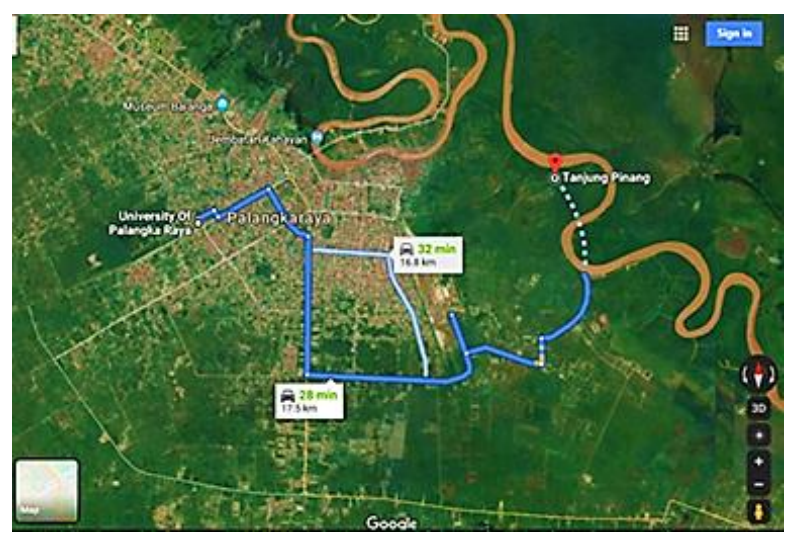

Gambar 1. Lokasi kegiatan PDPPM

Peserta kegiatan adalah anggota Poktan Rukun Bersama, PPL, mahasiswa dan anggota Poktan lainnya, total peserta berjumlah 15 orang. Metode yang digunakan dalam kegiatan transfer teknologi ini yaitu penyampaian materi (Gambar 2) dan praktek secara langsung pembuatan Trichokompos (Gambar 3) merujuk pada metode Supriati et al. (2019).

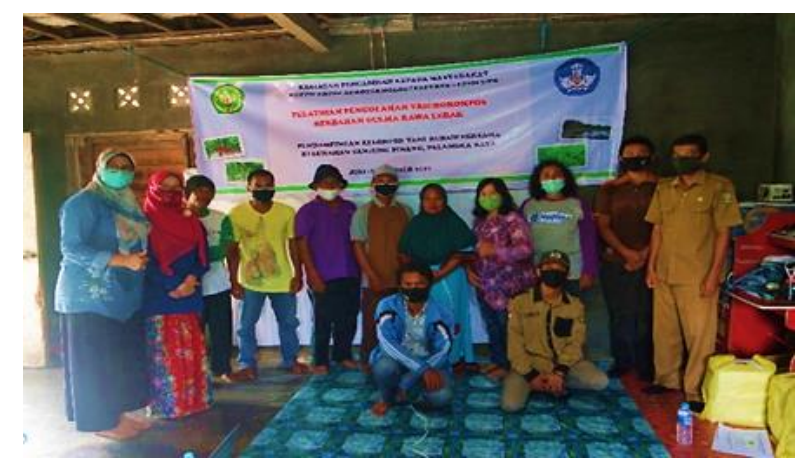

Gambar 2. Peserta pelatihan setelah penyampaian materi

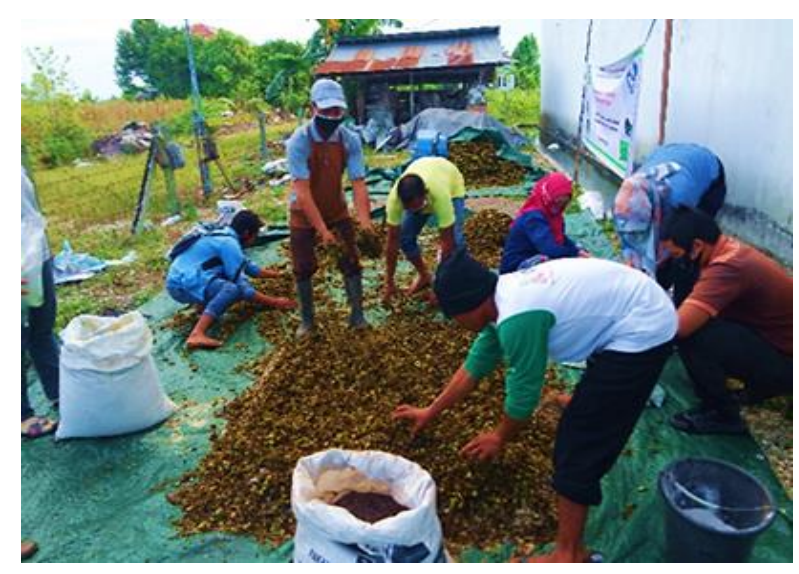

Gambar 3. Praktek pengolahan Trichokompos

Bahan-bahan yang digunakan adalah 5 karung Kayambang segar yang sudah ditiriskan 1 hari sebelumnya (masing-masing berisi $12 \mathrm{~kg}$ ). Pakan ayam $50 \mathrm{~kg}$, dolomit $300 \mathrm{~g}$, dedak $3 \mathrm{~kg}$ dicampur merata dan dibagi menjadi 4 bagian, 4 bungkus subtrat padat masing-masing berisi $100 \mathrm{~g}$ konsorsium T. koningii, $T$. longibrachiatum dan Gliocladium (isolat koleksi pribadi hasil penelitian) (Gambar 4).

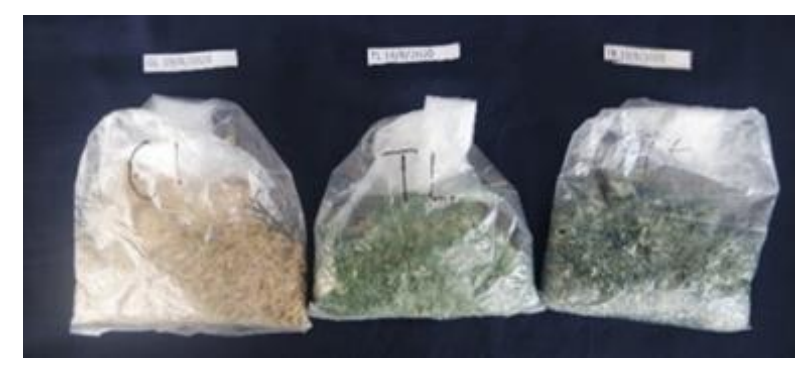

Gambar 4. Substrat padat agens hayati dalam media beras

Alat-alat yang digunakan antara lain mesin pencacah gulma Type CP 15, WEMA 6.5 HP kapasitas 250 kg/jam (Gambar5). 


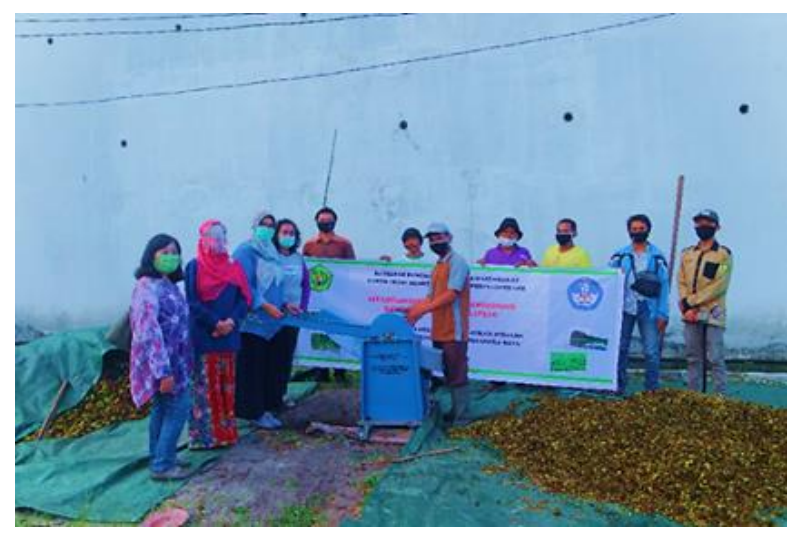

Gambar 5. Penyerahan mesin pencacah gulma kepada Ketua Poktan Rukun Bersama

Proses pembuatan Trichokompos diawali dengan menghamparkan 1 bagian serasah kayambang di atas terpal, sebarkan secara merata 1 bagian campuran pukan+dedak+dolomit di atasnya, tambahkan 1 bungkus substrat Trichoderma, kemudian siram menggunakan gembor permukaannya dengan air hingga lembab (lapisan 1). Proses yang sama diulang untuk membuat lapisan II, III, dan IV. Proses terakhir adalah menaburkan serasah kayambang di bagian atas. Tumpukan lapisan kompos ditutup dengan terpal selama 1 minggu, kemudian dilakukan pembalikan lapisan kompos, bila kompos terlihat kering siram dengan air secukupnya agar lembab. Pada proses pembalikan kompos lakukan pengukuran suhu menggunakan termometer, bila kompos terasa panas menandakan suhu meningkat, maka buka terpal untuk menurunkan suhu, kemudian tutup kembali (Gambar 6).

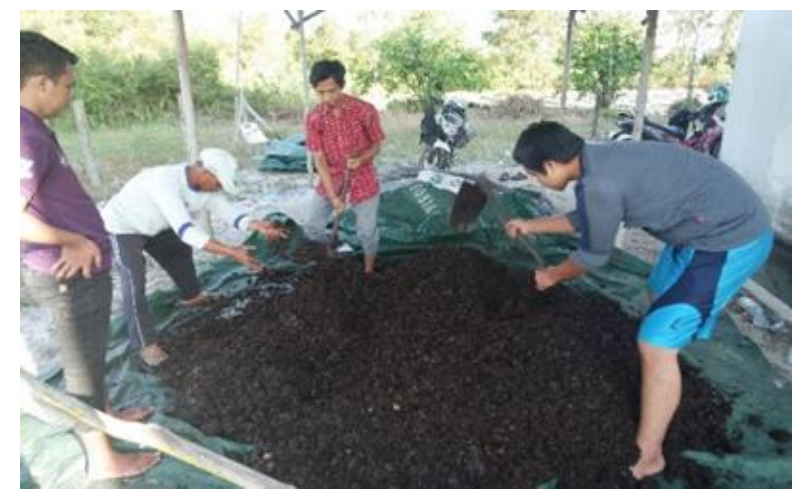

Gambar 6. Proses pembalikan kompos
Setelah 2 minggu kompos berubah warna menjadi kecoklatan, bentuk bahan lebih halus dan Trichokompos siap diaplikasikan ke lahan berpasir.

\section{HASIL DAN PEMBAHASAN}

Setelah 3 minggu inkubasi, Trichokompos sudah matang dan siap untuk diaplikasikan ke lahan. Beberapa ciri-ciri umum pupuk kompos yang baik adalah tidak berbau busuk, memiliki bau yang sama dengan tanah, warna coklat kehitaman, berbentuk butiran gembur seperti tanah, jika dimasukkan ke dalam air seluruhnya tenggelam, dan air tetap jernih tidak berubah warna, dan jika diaplikasikan pada tanah tidak memicu tumbuhnya gulma (Kusrinah et al., 2016). Metode pengomposan yang dilakukan yaitu secara aerob dipermukaan tanah. Menurut Simanungkalit et al. (2006), metode yang digunakan ini disebut Metode Berkeley. Bahan dasar yang digunakan adalah bahan organik kaya selulosa dan bahan organik kaya nitrogen dengan nilai rasio C/N 30 : 1. Bahan disusun berlapis-lapis hingga ketebalan tertentu sesuai yang diinginkan. Setelah 2-3 hari proses pengomposan berjalan terbentuk suhu tinggi, secara berkala kompos harus dibalik. Setelah hari ke10, suhu mulai menurun dan bahan berubah menjadi remah dan berwarna coklat gelap. Pengomposan selesai setelah 2 minggu. Selain bahan utama sebagai bahan dasar pembuatan kompos diperlukan bahan lain seperti dekomposer/aktivator, dedak, dolomit dan air. Pembuatan kompos secara alamiah memerlukan waktu yang lama, oleh karena itu ditambahkan dekomposer untuk mempercepat proses pengomposan (Nur et al., 2016). Jenis dekomposer yang ditambahkan dapat berasal dari bahan-bahan organik yang ada di sekitar lingkungan petani seperti bonggol pisang, daun gamal, rebung, sisa buah-buahan dan lain lain, sumberdaya hayati mikroba lokal (indigenus) seperti Trichoderma sp. dan Gliocladium sp. yang diisolasi dari tanah gambut, 
maupun berupa dekomposer komersil yang sudah banyak dijual di toko-toko pertanian. Efektivitasnya tergantung pada jenis mikroba yang digunakan dan kemampuan mikroba tersebut berkembang biak pada bahan organik yang dikomposkan.

Deskripsi varietas terung hijau yang ditanam adalah Hitavi F1, tahan Virus Gemini dan tahan layu bakteri (Ralstonia solanacearum). Produksi tinggi lebih dari 4,6 kg per tanaman. Tanaman vigor, bentuk buah silindris, warna buah hijau-mengkilap dengan tekstur permukaan buah yang halus. Kondisi pertumbuhan umur 7 MST, dan kondisi tanaman siap dipanen ditampilkan pada Gambar 7 dan 8.

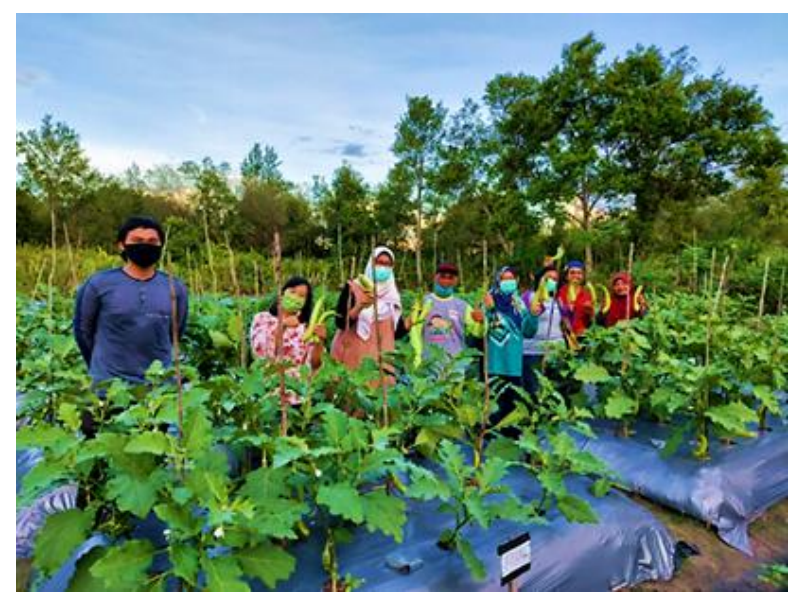

Gambar 7. Kondisi pertumbuhan tanaman terung umur 7 MST pada demplot aplikasi Trichokompos

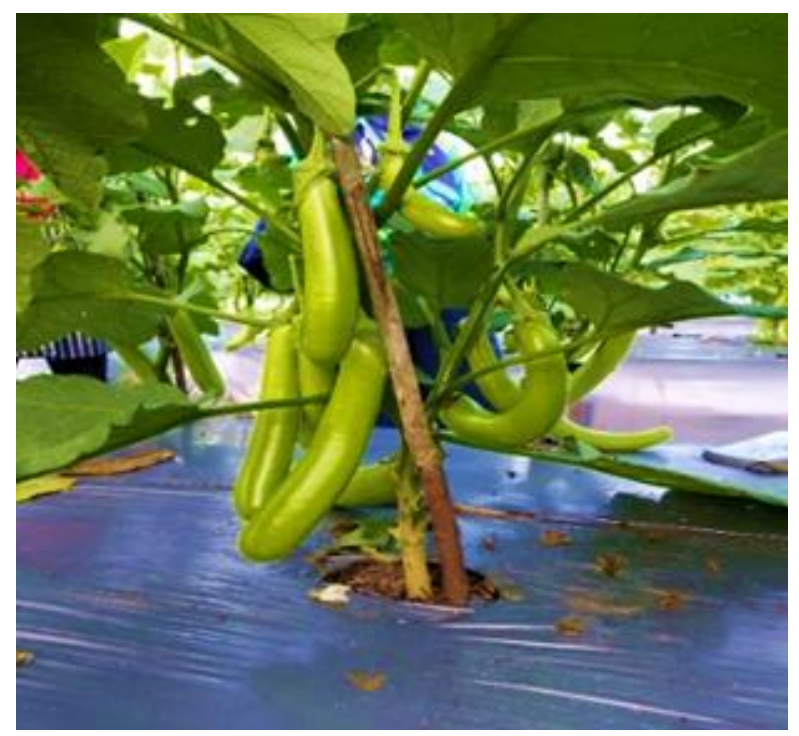

Gambar 8. Kondisi tanaman terung siap panen
Secara visual tanaman terung yang dipupuk dengan Trichokompos pertumbuhannya sangat baik dan sehat, tidak ditemukan serangan penyakit tular tanah. Serangan hama orong-orong pada awal tanam dapat diatasi dengan pestisida nabati tembakau. Trichokompos yang mengandung konsorsium jamur Trichoderma sp. dan Gliocladium sp. memiliki manfaat untuk mencegah serangan penyakit tanaman yang ditularkan melalui tanah (biofungisida), dan mempercepat proses pelapukan bahan organik seperti gulma, dan sisa tanaman lainnya (dekomposer) serta berperan sebagai stimulator pertumbuhan tanaman (Plant Growth Promoting Fungi).

Peningkatan pengetahuan melalui transfer teknologi pembuatan pupuk Trichokompos memberikan manfaat yang besar bagi anggota kelompok tani Rukun Bersama di kelurahan Tanjung Pinang. Diharapkan petani dapat melanjutkan kegiatan pembuatan pupuk Trichokompos dari gulma rawa maupun bahan-bahan organik lainnya yang ada di sekitar lingkungan mereka. Sesuai dengan tujuan kegiatan, pelatihan ini sebagai upaya untuk mencapai kemandirian petani dalam swadaya pupuk organik, memperbaiki kesuburan lahan pasir dan pertumbuhan tanaman, mewujudkan ketahanan pangan dan sebagai tahap awal menuju desa pertanian organik.

\section{KESIMPULAN}

Berdasarkan hasil evaluasi sebanyak $86,7 \%$ petani menyatakan kegiatan pelatihan Trichokompos ini merupakan pengetahuan yang baru yang sangat baik dan sangat bermanfaat. Pada pendampingan budidaya tanaman, seluruh peserta pelatihan (100\%) menyatakan bahwa aplikasi Trichokompos berpengaruh sangat baik (100\%) terhadap pertumbuhan tanaman dan hasil panen terung, menunjukkan bahwa Trichokompos dapat memperbaiki kesuburan lahan berpasir. Sebanyak 86,7\% 
peserta pelatihan menyatakan bahwa penggunaan Trichokompos dapat mengurangi biaya usaha tani karena mampu mensubstitusi pupuk kandang dan pupuk kimia. Sebanyak $90 \%$ peserta menginginkan adanya program pendampingan lanjutan mengenai teknik isolasi maupun perbanyakan agen hayati secara mudah dan dapat dilakukan petani dengan peralatan yang sederhana.

\section{UCAPAN TERIMA KASIH}

Ucapan terima kasih serta penghargaan disampaikan kepada LPPM UPR yang telah mendanai kegiatan Program Dosen Pendamping Pemberdayaan Masyarakat melalui dana DIPA PNBP UPR tahun Anggaran 2020 dengan nomer kontrak 336/UN24.13/PM/2020, tanggal 23 Juli 2020. Penghargaan juga disampaikan kepada Bapak Ahmad Yani selaku Ketua Poktan Rukun Bersama yang telah bersedia menjadi mitra dan menyediakan lahan sebagai demplot kegiatan. Terima kasih kepada Andrey Hutajulu, Barnabas, dan Catur Kasyanto, mahasiswa Prodi Agroteknologi Fakultas Pertanian UPR yang telah membantu kegiatan baik di laboratorium maupun di lapangan.

\section{REFERENSI}

Badan Pusat Statistik Kota Palangka Raya. 2018. Kecamatan Pahandut Dalam Angka 2018. Palangka Raya: Badan Pusat Statistik Kota Palangka Raya

Firmansyah, M.A., Yuliani, N., Nugroho, W.A. 2011. Pengkajian Paket Pemupukan Anorganik Tanaman Semangka Tanpa Biji di Tanah Pasir Kuarsa. In Prosiding Seminar Nasional Akselerasi Pembangunan Pertanian dan Perdesaan Berbasis Inovasi dan Sumber Daya Lokal. Balai Besar Pengkajian dan Pengembangan Teknologi Pertanian, Bogor, 304-310.

Hasibuan, A.S.Z. 2015. Pemanfaatan Bahan Organik dalam Perbaikan Beberapa Sifat Tanah Pasir
Pantai Selatan Kulon Progo. Planta Tropika: Jurnal Agrosains (Journal of Agro Science). 3(1):3140. https://doi.org/10.18196/pt.2015.037.3140

Holilullah, H., Afandi, A., Novpriansyah, H. 2015. Karakterisitk Sifat Fisik Tanah Pada Lahan Produksi Rendah Dan Tinggi Di PT Great Giant Pineapple. Jurnal Agrotek Tropika. 3(2):278-282. http://dx.doi.org/10.23960/jat.v3i2.2014

Kresnatita, S. 2017. Respon Pertumbuhan Dan Hasil Tanaman Seledri Akibat Pemberian Bokashi Kayambang dan Abu di Tanah Gambut. Jurnal Agripeat. 18(1):46-57.

Kusrinah, K., Nurhayati, A., Hayati, N. 2016. Pelatihan dan Pendampingan Pemanfaatan Eceng gondok (Eichornia crassipes) Menjadi Pupuk Kompos Cair Untuk Mengurangi Pencemaran Air dan Meningkatkan Ekonomi Masyarakat Desa Karangkimpul Kelurahan Kaligawe Kecamatan Gayamsari Kotamadya Semarang. Dimas: Jurnal Pemikiran Agama untuk Pemberdayaan. 16(1):27-48. https://doi.org/10.21580/dms.2016.161.890

Masruddin, Aphrodyanti, L., Mariana. 2019. Pemanfaatan Beberapa Gulma Air Sebagai Media Aplikatif Trichoderma sp. untuk Mengendalikan Penyakit Jamur Akar Puth (Rigidoporus lignosus) pada Tanaman Karet. Jurnal Proteksi Tanaman Tropika. 2(2):102-107.

Mulyani, R.B., Panupesi, H., Nion, Y.A., Gustiara, T. 2018. Potensi Trichoderma longibrachiatum Asal Perakaran Kalakai (Stenochlaena palustris) Tanah Gambut Menekan Fusarium oxysporum f.sp. cubense. In Prosiding Seminar Nasional dan Kongres Perhimpunan Fitopatologi Indonesia 2018. Universitas Halu Oleo, Kendali, 393-401.

Noor, M. 2007. Rawa Lebak: Ekologi, Pemanfaatan, dan Pengembangannya. Jakarta: Rajawali Pers

Nur, T., Noor, A.R., Elma, M. 2016. Pembuatan Pupuk Organik Cair Dari Sampah Organik Rumah Tangga Dengan Bioaktivator EM4 (Effective Microorganisms). Konversi. 5(2):5-12. http://dx.doi.org/10.20527/k.v5i2.4766

Pemerintah Kota Palangka Raya. 2019. Rencana Pembangunan Jangka Menengah Daerah (RPJMD) Kota Palangka Raya Tahun 2018-2023. 
Palangka Raya: Pemerintah Kota Palangka Raya

Simanungkalit, R.D.M., Suriadikarta, D.A., Saraswati, R., Setyorini, D., Hartatik, W. 2006. Pupuk Organik dan Pupuk Hayati. Bogor: Balai Besar Penelitian dan Pengembangan Sumberdaya Lahan Pertanian.

Soesanto, L., Mugiastuti, E., Rahayuniati, R.F., Dewi, R.S. 2013. Uji Kesesuaian Empat Isolat Trichoderma spp. dan Daya Hambat In Vitro Terhadap Beberapa Patogen Tanaman. Jurnal Hama dan Penyakit Tumbuhan Tropika. 13(2):117-123.

https:/ /doi.org/10.23960/j.hptt.213117-123

Supriati, Basuki, Mulyani, R.B., Muliansyah, Muliana. 2019. Peranan Trichokompos Dan Pupuk Kcl Dalam Mengendalikan Penyakit Layu Fusarium Pada Tanaman Bawang Merah Di Tanah Berpasir (The Role of Trichokompos and KCL Fertilizer to Control Fusarium Will Disease on Onion in Sandy Soil). Jurnal Agripeat. 20(1):19-26. https://doi.org/10.36873/agp.v20i01.21 